\title{
Joint Conference of the British Society for Oral \& Maxillofacial Pathology and Scandinavian Society of Oral Pathology \& Medicine, Cardiff Bay, 27-28 April 2017
}

$\mathrm{N}$ inety delegates attended the St. David's Hotel in Cardiff Bay and proceedings began with a session in which undergraduate and postgraduate education in oral pathology in Scandinavia and the UK was compared and contrasted by Paula Farthing (Sheffield), Gunnar Warfvinge (Malmö), Keith Hunter (Sheffield), Paul Speight (Sheffield), Kim Piper (Barts \& the London) and Stina Syrjänen (Turku).

Coffee was followed by six presentations reporting original clinical and laboratory-based research on subjects as diverse as the importance of radiology in avoiding inappropriate histological diagnoses of dentigerous cysts, polyoma virus in adenoid cystic carcinoma, genetic differences between unicystic and conventional ameloblastoma, immune surveillance in oral cancer, lysyl oxidase in odontogenic lesions and amyloidoma of the palate. There were also 22 posters, for which three prizes were up for grabs, judges Liv Kroona (Malmö), Miranda Pring (Bristol), Kathrine Skarstein (Bergen) and Sharon White (Dundee) having an unenviable task.

After lunch a panel of experts, comprising Jesper Reibel (Copenhagen), Paul Speight and Phil Sloan (Newcastle) and Eddy Odell (Guy's/King's), reviewed the World Health Organisation's recent changes to the classification of odontogenic cysts and tumours, oral and oropharyngeal cancer, epithelial dysplasia and salivary gland tumours.

Delegates were then bussed to Cardiff Castle for the conference dinner, a banquet accompanied by traditional and modern Welsh music and poetry energetically performed by the Bute Boys \& Babes.

BSOMP President Paula Farthing presented the prizes to the three winners: Jennifer Graham (Leeds, 'When histomorphology and copy number data disagree'), Lisette Martin (Sheffield, 'The spectrum of histological features in head and neck clear cell lesions'), and Stephen James Brown (Sheffield, 'Characterisation of p63 function in squamous cell carcinoma').

For the Friday morning session the impressive Stefan Dojcinov and Anurag Joshi of the All Wales Lymphoma Panel provided a comprehensive update on lymphomas of the head and neck, followed by seven case-based discussions. Finally, on the Friday afternoon Gill Hall (Guy's/King's) deftly chaired the National Head \& Neck Pathology External Quality Assurance Scheme review session in which two circulations of 18 cases were debated with the customary vigour. Diagnostic consensus was reached in all but two cases, one a palatal adenocarcinoma (polymorphous adenocarcinoma or adenoid cystic carcinoma?), the other an acantholytic oral leukoplakia (pemphigus vulgaris or Darier's disease?). This stimulating educational discussion brought the curtain down on an academically and socially successful gathering held in excellent facilities at a fine venue, for which local organisers Adam Jones and John Potts are to be congratulated.

Next year's conference will be held in Sheffield. For more information contact Rachel Hall, BSOMP secretary (RachelClare.Hall@pat.nhs.uk).

By DrA.W. Barrett

\section{Nigel Harradine to headline orthodontic conference}

Nigel Harradine will be reflecting on landmark innovations in orthodontics when he takes the stage at the British Orthodontic Conference in Manchester on 14-16 September.

Dr Harradine, one of the UK's best known and most thought-provoking lecturers in orthodontics over the last four decades, will be speaking on ' 40 years in orthodontics - what has changed?', a talk that is billed as his last major public presentation, and expected to attract many colleagues.

Dr Harradine will be embracing the conference theme of Back to the Future, discussing advances such

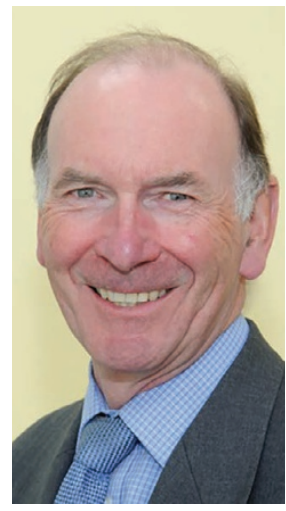

as the journey from the early use of Begg brackets to self-ligation and from headgear to temporary anchorage devices. As well as describing ways in which treatment mechanics have changed, he will examine the way in which orthodontists have responded to innovations, comparing for example the reaction to the advent of the Straight Wire Appliance and nickel-titanium wires to the response to more recent innovations. He will observe that whilst not every new development is for the best, we are prone to linger too long in our comfort zones.

For more information on the Conference, visit www.bos.org.uk/BOC-Manchester-2017. 